\title{
Zmiany struktury agrarnej na polskiej wsi w latach 1918-2018
}

\author{
Changes in the agrarian structure \\ of the Polish countryside \\ in the years $1918-2018$
}

Wstęp

Pojęcie struktury agrarnej w literaturze jest w różny sposób definiowane. Różnice te są zarówno wyrazem indywidualnych poglądów poszczególnych autorów, jak i dyscyplin, które reprezentują. Dodatkowo pojęcie to ewoluowało wraz z rozwojem nauk rolniczych oraz zachodzących w rolnictwie przemian społeczno-gospodarczych. Wśród ekonomistów rolnych jedną z pierwszych definicji tego pojęcia podał Konstanty Czerniewski (1937), który strukturę agrarną określił jako „ujęcie liczby warsztatów rolnych w grupy według wielkości i w powiązaniu z kształtowaniem się szachownicy, serwitutów i wspólnot, tytułów władania oraz częściowo użytkowania gruntów"'. Zdaniem Aleksandry Oleszko, struktura agrarna obejmuje elementy prawne oraz ekonomiczne, które kształtują system władania ziemią, obejmujący wszelkie formy stosunków własnościowych w rolnictwie, a także konfigurację gruntów (rozdrobnienie), typ i charakter produkcji rolnej w konkretnych grupach gospodarstw rolnych (małorolnych, średniorolnych, wielkorolnych, specjalistycznych) oraz zasobność gospodarstw w inne - poza ziemią - środki produkcji ${ }^{2}$. Z kolei Anna Szemberg pojęcie struktury agrarnej zdefiniowała jako rozkład gospodarstw chłopskich według ich obszaru, przy założeniu, że ziemia jest decydującym czynnikiem

1 K. Czerniewski, Zagadnienia struktury agrarnej, Warszawa 1937,

2 A. Oleszko, Prawo rolne, [w:] Encyklopedia Agrobiznesu, Warszawa 1998, s. 594-602. 
produkcji, a wszystkie pozostałe czynniki są z nią liniowo skorelowane ${ }^{3}$. Na podstawie przeglądu definicji strukturę agrarną można zatem określić jako zróżnicowanie gospodarstw rolnych pod względem powierzchni użytków rolnych (UR), rozdrobnienia działek oraz struktury własnościowej.

Zdaniem Jerzego Wilkina, kwestia agrarna „oznacza taką sytuację społeczno-ekonomiczną, w której rolnictwo i jego problemy stają się bądź elementem naruszającym równowagę ekonomiczną i społeczną w ramach systemu gospodarki narodowej, bądź ze względu na swe szczególne cechy są hamulcem rozwoju gospodarczego i społecznego"4. W dużym stopniu struktura agrarna jest uzależniona od warunków przyrodniczych, głównie glebowych, cen ziemi, od historii kraju, regionu, a także jest rezultatem stosunków politycznych i społeczno-gospodarczych ${ }^{5}$. Ewolucja struktury agrarnej dokonuje się pod wpływem bardzo wielu czynników, zarówno endogenicznych, jak i egzogenicznych. Istotne są także zmiany zachodzące $\mathrm{w}$ zakresie sił wytwórczych $\mathrm{w}$ rolnictwie oraz poza nim ${ }^{6}$. Irena Augustyńska-Grzymek do czynników najsilniej oddziałujących obecnie na strukturę agrarną zaliczyła: urbanizację obszarów wiejskich, spadek udziału ludności wiejskiej w ogólnej liczbie mieszkańców kraju (deruralizacja), zmniejszenie areału obszarów wiejskich wykorzystywanych do produkcji rolniczej, zmniejszenie udziału dochodów rolniczych w dochodach gospodarstw domowych rodzin wiejskich (dezagraryzacja), zmianę struktury własności ziemi oraz gospodarstw rolnych i charakteru ich funkcjonowania (dualizacja), a także zmiany struktury zawodowej mieszkańców wsi (restratyfikacja) ${ }^{7}$.

Struktura agrarna ma kluczowe znaczenie w rozwoju rolnictwa. Wynika to $\mathrm{z}$ wielu powodów, z których najważniejszy jest związek statystyczny wielkości obszarowej gospodarstwa z dochodami rolniczymi, wydajnością pracy oraz efektywnością ekonomiczną. Ponadto jest odzwierciedleniem decyzji ekonomicznych podejmowanych przez producentów rolnych. Według Andrzeja Czyżewskiego i Anny Henisz-Matuszczak, stanowi ona

3 A. Szemberg, Struktura agrarna i polityka strukturalna, [w:] Encyklopedia Agrobiznesu, Warszawa 1998, s. 867-875.

4 J. Wilkin, Wspótczesna kwestia agrarna, Warszawa 1986, s. II-50.

5 R. Marks-Bielska, R. Kisiel, J. Danilczuk, Dzierżawa jako podstawowa forma zagospodarowania popegeerowskiego mienia, Olsztyn 2006.

6 B. Klepacki, A.Żak, Przemiany agrarne na terenach polskich przed i po integracji z Unia Europejska, ,Journal of Agribusiness and Rural Development" 2014, nr 4 (30), s.95-II3.

7 I. Augustyńska-Grzymek, Zmiany spoteczno-gospodarcze na wsi a ukierunkowanie produkcyjne w gospodarstwach rolnych, „Roczniki Naukowe SERIA” 20II, t. XIII, z. I, s. 26-3I. 
jeden z podstawowych czynników wpływających na zasób i przepływy czynników wytwórczych, determinujących sytuację na rynkach rolnych ${ }^{8}$.

Poszukując sposobów unowocześnienia rolnictwa, wzrostu jego konkurencyjności oraz dochodów z prowadzonej działalności rolniczej, najczęściej wskazuje się na konieczność poprawy struktury agrarnej, tj. stanu rolniczych jednostek wytwórczych ${ }^{9}$. Zdaniem Józefa Zegara, od kilku dziesięcioleci podlega ona przeobrażeniom polegającym na ogólnym spadku liczby gospodarstw oraz polaryzacji struktury obszarowej, czyli zwiększaniu udziału gospodarstw obszarowo najmniejszych (do 5 ha) i największych (30 ha i powyżej) w strukturze gospodarstw rolnych w Polsce ${ }^{10}$.

Zagadnienia związane ze strukturą agrarną były już analizowane w literaturze, ale szczególnego znaczenia nabrały po przystąpieniu Polski do Unii Europejskiej w kontekście dostosowywania się polskich gospodarstw rolnych do możliwości konkurowania z gospodarstwami w UE. Ponadto, dostępne opracowania dotyczą najczęściej wybranych okresów historycznych" albo zmian regionalnych ${ }^{12}$, co utrudnia wnioskowanie. Przygotowane opracowanie obejmuje okres od I9I8 roku do pierwszych dziesięcioleci XXI w. Aby zrozumieć sytuację w rolnictwie Polski międzywojennej, poczyniono uwagi dotyczące polityki zaborców wobec podporządkowanych im terytoriów. Rozpoznanie zmian w strukturze agrarnej na polskich ziemiach w tak długim okresie jest ważne dla zrozumienia procesów gospodarczych w ujęciu historycznym. Uzyskane wyniki mogą być także wykorzystane w praktyce gospodarczej, stanowiąc podstawę do prognozowania i programowania rozwoju polskiego rolnictwa. Znajomość kierunków i uwarunkowań zmian w strukturze agrarnej jest niezbędna do prawidłowego formułowania celów polityki rolnej. Celem analiz było zatem rozpoznanie zmian w strukturze

8 A. Czyżewski, A. Henisz-Matuszczak, Rolnictwo w Unii Europejskiej i Polsce. Studium porównawcze struktur wytwórczych i regulatorów rynków rolnych, Poznań 2006.

9 M.B. Pietrzak, D. Walczak, The analysis of the agrarian structure in Poland with the special consideration of the years 192I and 2002, "Bulgarian Journal of Agricultural Science” 2014, No. 20, s. 1018-1039.

$10 \mathrm{~J}$. S.Zegar, Kwestia koncentracji ziemi w polskim rolnictwie indywidualnym, „Roczniki Nauk Rolniczych" 2009, t. 96, z. 4, s. 256-266.

11 J.Kaliński, Przemiany struktury obszarowej gospodarstw chtopskich w Polsce po IgI8 roku, „Kwartalnik Kolegium Ekonomiczno-Społecznego Studia i Prace” 2019, nr 3, s. I2I-I43; A.M. Sikorska, Przemiany w strukturze agrarnej indywidualnych gospodarstw rolnych, Warszawa 2013.

12 J. Bożek, D. Bogocz, Przestrzenne zróżnicowanie struktury agrarnej województw w ujęciu dynamicznym, „Zeszyty Naukowe Małopolskiej Wyższej Szkoły Ekonomicznej w Tarnowie" 20I2, t. 20, nr I, S. 2I-38. 
agrarnej na polskiej wsi w ostatnim stuleciu. W analizach wykorzystano dane z opracowań historycznych oraz Głównego Urzędu Statystycznego. Istotnym źródłem informacji były także studia literatury przedmiotu.

\section{Struktura agrarna w okresie międzywojennym}

W okresie międzywojennym charakterystyczną cechą struktury agrarnej było jej silne zróżnicowanie przestrzenne. Wynikało ono w znacznej mierze z warunków społeczno-ekonomicznych, w jakich rozwijało się rolnictwo w czasie zaborów. Zdaniem Mieczysława Mieszczankowskiego, ewolucję struktury agrarnej w okresie przed I wojną światową kształtowały cztery zasadnicze procesy:

- systematyczne kurczenie się wielkiej własności rolnej,

- powolny rozwój chłopskich gospodarstw kapitalistycznych,

- wzrost ilościowy gospodarstw średniorolnych i utrzymywanie ich pozycji w strukturze agrarnej,

- rozdrabnianie gospodarki chłopskiej (szybki wzrost liczby gospodarstw małorolnych i półproletariackich) ${ }^{13}$.

Te procesy przebiegały jednak odmiennie w trzech różnych zaborach. Wpłynęły na to różnice w stopniu rozwoju gospodarczego państw zaborczych oraz reformy uwłaszczeniowe zapoczątkowane w poszczególnych zaborach w różnych latach: w $1807 \mathrm{r}$. w zaborze pruskim, w I848 r. w zaborze austriackim oraz w $1864 \mathrm{r}$. w zaborze rosyjskim. Ich przebieg, zastosowane metody oraz osiągnięte rezultaty pogłębiły różnice regionalne. We wszystkich zaborach charakterystyczna była silna polaryzacja struktury obszarowej gospodarstw. W największym stopniu była ona widoczna na terytorium Wielkiego Księstwa Poznańskiego (zabór pruski), gdzie najmniejsze gospodarstwa (półproletariackie) o obszarze $0-2$ ha stanowiły 55,1\% ogólnej liczby gospodarstw rolnych i zajmowały tylko 2,7\% użytków rolnych, podczas gdy gospodarstwa największe (folwarki i własność państwowa) o powierzchni powyżej 50 ha obejmowały $51,7 \%$ obszaru UR, posiadając jedynie I,9\% udziału w ogólnej liczbie gospodarstw. Największe jednak rozdrobnienie gospodarstw rolnych miało miejsce w Galicji (zabór austriacki). Gospodarstwa posiadające do 5 ha UR stanowiły tam 81,5\% wszystkich gospodarstw i zajmowały tylko $28,4 \%$ ogólnego obszaru (tab. I).

Po odzyskaniu przez Polskę niepodległości władze stanęły przed bardzo trudnym zadaniem ukierunkowania rozwoju gospodarczego kraju,

13 M. Mieszczankowski, Rolnictwo II Rzeczypospolitej, Warszawa 1983. Cyt. za: E. Grzelak, Polskie rolnictwo $w X X$ wieku (Produkcja i ludność), Warszawa 2010, s. 102. 
TAB. 1 Struktura agrarna na ziemiach polskich na początku XX w.

\begin{tabular}{|c|c|c|c|c|c|c|}
\hline \multirow{2}{*}{$\begin{array}{r}\text { Obszar } \\
\text { gospodarstw }\end{array}$} & \multicolumn{3}{|c|}{ Liczba gospodarstw w \% } & \multicolumn{3}{|c|}{ Obszar w \% } \\
\hline & Królestwo & Galicja & Poznańskie & Królestwo & Galicja & Poznańskie \\
\hline do 2 ha & 22,8 & 46,2 & 55,1 & 2,5 & 8,1 & 2,7 \\
\hline $2-5$ ha & 34,1 & 35,3 & 12,6 & 12,7 & 20,3 & 4,1 \\
\hline 5-10 ha & 27,4 & 13,6 & 12,4 & 19,4 & 16,1 & 8,3 \\
\hline 10-15 ha & 11,8 & 3,5 & 12,5 & 15,6 & 8,2 & 17,4 \\
\hline $20-50$ ha & 3,0 & 0,7 & 5,5 & 8,7 & 4,0 & 15,8 \\
\hline 15 ha i więcej & 0,9 & 0,7 & 1,9 & 41,1 & 43,3 & 51,7 \\
\hline
\end{tabular}

Źródło: S. Kieniewicz, Historia Polski 1795-19I8, Warszawa 1983, s. 276.

którego ważną częścią składową była gospodarka rolna. W celu zmiany niekorzystnej struktury agrarnej wsi już w 1919 r. sejm przyjął uchwałę o parcelacji majątków państwowych i wykupie nadwyżek ziemi w majątkach prywatnych. $Z$ powodu sporów politycznych uchwała nie weszła jednak w życie. Bardziej radykalny wariant reformy został przyjęty przez sejm w lipcu $1920 \mathrm{r}$. Uchwalona wówczas ustawa o wykonaniu reformy rolnej przewidywała przymusowy wykup nadwyżek ziemi w majątkach prywatnych (powyżej 60 ha w okręgach przemysłowych, powyżej 400 ha na obszarze byłego zaboru pruskiego i na ziemiach wschodnich oraz 180 ha na pozostałym obszarze państwa) ${ }^{14}$. Wywłaszczani właściciele mieli otrzymać odszkodowania na poziomie 50\% przeciętnej wartości rynkowej ziemi. Decyzja ta wywołała liczne protesty środowisk ziemiańskich i endecji ${ }^{15}$. Po wejściu w życie konstytucji marcowej z I92I r., realizacja reformy napotkała poważne przeszkody, ponieważ parcelacja majątków bez pełnego odszkodowania właścicielom była niezgodna z konstytucyjnym zapisem, iż własność prywatna jest nienaruszalna ${ }^{16}$. W praktyce parcelację ograniczono więc głównie do majątków państwowych oraz do działań podejmowanych prywatnie przez właścicieli ziemi.

14 J. Skodlarski, Zarys historii gospodarczej Polski, Warszawa 2007, s. 250.

15 M. Michałek, Przemiany polskiej wsi w latach I9I8-1989, „Klio” 2013 , nr 26 (3), s. 55-80.

16 Cz. Noniewicz, Reforma rolna na Wileńszczyźnie w okresie międzywojennym, „Optimum. Studia ekonomiczne" 2014, nr 6 (72), s. 236-241. 
W I92 I r. 45\% użytków rolnych należało do i8,9 tys. gospodarstw o powierzchni ponad Ioo ha, z których 1964 przekraczało Iooo ha powierzchni. Najwięcej wielkich majątków znajdowało się na Kresach Wschodnich oraz w Wielkopolsce, na Pomorzu i na Śląsku. Tymczasem jeden mln gospodarstw chłopskich o powierzchni nieprzekraczającej 2 ha posiadało zaledwie $2,8 \%$ gruntów. Dochody z tych gospodarstw nie gwarantowały utrzymania rodzinom chłopskim i zmuszały do szukania dodatkowych zarobków, głównie przy pracach sezonowych ${ }^{17}$.

W poszczególnych dzielnicach kraju gospodarstwa znacznie różniły się pod względem poziomu zagospodarowania, rodzaju produkcji oraz wielkości osiąganych plonów. W województwach zachodnich wykorzystywano nowoczesne metody gospodarowania a praca była w dużej części zmechanizowana. Ponadto, stosowano tam duże ilości nawozów sztucznych. Istniał też rynek zbytu na produkty rolne wywożone głównie w głąb Niemiec. $\mathrm{Z}$ kolei na ziemiach byłego zaboru rosyjskiego nastąpiło poważne rozdrobnienie gospodarstw rolnych, będące efektem częstych podziałów ziemi. $\mathrm{Na}$ wsi dominowały gospodarstwa drobnotowarowe prowadzące gospodarkę ekstensywną, a na słabym rynku zbytu istniała silna konkurencja w postaci tanich towarów przywożonych z głębi Rosji. Jeszcze większym rozdrobnieniem i przeludnieniem charakteryzowały się województwa południowe (dawna Galicja) ${ }^{18}$.

Ze względu na brak możliwości realizacji reformy rolnej według ustawy z 1920 r. na terenie prywatnej własności podjęto prace nad zmianą przepisów. Ich efektem był nowy projekt ustawy o reformie rolnej przyjęty przez sejm w czerwcu 1925 r., który uwzględniał dobrowolną parcelację majątków ziemskich. Ustawa weszła w życie na początku 1926 r. i zakładała coroczny kontyngent parcelacji na poziomie 200 tys. ha (przez ıo lat). Jeśli dobrowolna parcelacja majątków byłaby mniejsza, to rząd był ustawowo upoważniony do uzupełnienia kontyngentu przymusową parcelacją z uwzględnieniem określonych w ustawie norm obszarowych ${ }^{19}$. Górną granicę powierzchni gospodarstw ustalono na 60-180 ha w Polsce centralnej oraz 300 ha na obszarze województw wschodnich i 700 ha dla majątków uprzemysłowionych (tj. mających na swoim terenie zakłady przetwórstwa rolnego). Odszkodowanie dla właścicieli było równe cenie rynkowej ziemi, a nabywcy mogli się ubiegać o specjalne kredyty na spłatę należności. W oparciu o ustawę z dnia 28 XII I925 r. ustalono, iż powierzchnia nowopowstających i uzupełnianych

17 M. Mieszczankowski, Struktura agrarna Polski międzywojennej, Warszawa 1960, s. 224.

18 M. Michałek, dz. cyt., s. 59.

19 Cz. Noniewicz, dz. cyt., s. 237. 
chłopskich gospodarstw rolnych nie mogła przekraczać 20 ha powierzchni na obszarze całego kraju z wyjątkiem województw wschodnich, gdzie powierzchnia tych gospodarstw mogła wynosić nawet do 35 ha. Przewidziano też tworzenie tzw. ośrodków naukowych, w których powierzchnia miała obejmować do 70 ha ziemi ${ }^{20}$. Reforma rolna była realizowana w różnym tempie przez wiele lat. Jej konsekwencją było zmniejszenie powierzchni wielkich majątków ziemskich i rozparcelowanie przeszło 2,6 $\mathrm{mln}$ ha gruntów ${ }^{21}$. Wprawdzie ziemia z parcelowanych majątków systematycznie zasilała istniejące już gospodarstwa chłopskie, jednak tradycyjne działy rodzinne powodowały, że obszar przeciętnego gospodarstwa wciąż malał. O ile w I92I r. średnia powierzchnia gospodarstwa chłopskiego wynosiła 5,7 ha, to w $1938 \mathrm{r}$.

TAB. 2 Struktura obszarowa gospodarstw indywidualnych w I92 I i 1938 r. (\%)

\begin{tabular}{|c|c|c|c|}
\hline \multirow{2}{*}{ Grupy gospodarstw } & \multicolumn{2}{|c|}{ Lata } & \multirow{2}{*}{ Zmiany } \\
\hline & 1921 & 1938 & \\
\hline poniżej 2 ha & 29,3 & 30,7 & 1,4 \\
\hline $2-5$ ha & 32,9 & 33,8 & 0,9 \\
\hline $5-10$ ha & 24,9 & 23,9 & $-1,0$ \\
\hline 10-15 ha & 10,4 & 9,5 & $-0,9$ \\
\hline 15 ha i więcej & 2,5 & 2,1 & $-0,4$ \\
\hline
\end{tabular}

Źródło: Historia Polski w liczbach, z. 2: Rolnictwo. Leśnictwo, Warszawa 1991, s. 194.

zmalała do 5 ha. Pod koniec lat 30. xx w. liczba gospodarstw małych, które nie były samowystarczalne, wzrosła do 64,5\% ogólnej liczby gospodarst $w^{22}$.

Zmiany w strukturze gospodarstw chłopskich w okresie międzywojennym, szczególnie pod wpływem reformy rolnej, przedstawiono w tabeli 2. $\mathrm{Z}$ danych wynika, że w tym okresie wbrew oczekiwaniom nastąpiło zwiększenie liczby najmniejszych gospodarstw (do 5 ha) oraz spadek dużych i największych (Io ha i więcej). W $1938 \mathrm{r}$. istniało $1,4 \mathrm{mln}$ gospodarstw o powierzchni do 2 ha, $1,5 \mathrm{mln}$ o obszarze od 2 do 5 ha oraz I,I $\mathrm{mln} \mathrm{z}$ areałem

20 K. Konopka, Konieczność reform agrarnych w Drugiej Rzeczypospolitej Polskiej (IgI8-1939), „Ekonomia i Zarządzanie” 2009, nr I (I), s. 7-19.

21 J.Kaliński, Z. Landau, Gospodarka Polski wXX wieku, Warszawa 2003, s. 64.

22 I. Kostrowicka, Z. Landau, J. Tomaszewski, Historia gospodarcza Polski XIX $i$ XX wieku, Warszawa 1984, s.363. 
5-Io ha, zaś tylko o, 4 mln gospodarstw dysponowało przeciętnym obszarem gruntów od Io do 50 ha. Tymczasem, jeszcze 1264 gospodarstw obszarniczych miało przeciętną powierzchnię przekraczającą Iooo ha.

Reforma rolna wprawdzie spowodowała pewne zmniejszenie "głodu ziemi" wśród chłopów, ale nie poprawiła struktury obszarowej należących do nich gospodarstw. Nie został zahamowany proces rozdrabniania własności chłopskiej, ze wszystkimi negatywnymi skutkami ekonomicznymi i społecznymi. Średni obszar gospodarstwa z 5,7 ha w I92I r. zmniejszył się do 5 ha w 1938 r. Szczególnie uciążliwe dla wsi w tym czasie było zwiększające się przeludnienie agrarne oraz nieopłacalność produkcji w gospodarstwach małorolnych.

\section{Czas II wojny światowej i okres gospodarki socjalistycznej}

W okresie II wojny światowej polska wieś poniosła ogromne straty. Już jesienią 1939 r. na obszarze ziem wcielonych do III Rzeszy Niemcy rozpoczęli wysiedlania Polaków do Generalnego Gubernatorstwa. Na opróżnionych gospodarstwach rolnych osiedlani byli Niemcy. Czasami dokonywano komasacji kilku gospodarstw, aby utworzyć jedno większe gospodarstwo dla niemieckiego kolonisty. Do lutego 1942 r. władze niemieckie skonfiskowały blisko 900 tys. gospodarstw o powierzchni 9,2 $\mathrm{mln} \mathrm{ha}^{23}$. Część chłopów, których nie wysiedlono z ziem włączonych do III Rzeszy, przestała być właścicielami własnych gospodarstw i poddano ich ścisłemu nadzorowi władz niemieckich, które decydowały o całości produkcji oraz wielkości konsumpcji własnej. Inna sytuacja była w Generalnym Gubernatorstwie, gdzie nie wprowadzono tak rygorystycznej kontroli nad całością produkcji rolnej. Rolnicy zostali wprawdzie obciążeni kontyngentami obejmującymi praktycznie wszystkie płody rolne, ale mieli ograniczony wpływ na rodzaj upraw i hodowli. Znaczną część produktów (np. 40\% zbóż, I8\% ziemniaków, 73\% buraków cukrowych) musieli sprzedawać po ustalonych urzędowo, bardzo niskich cenach, a jednocześnie wysokość kontyngentów była stale zwiększana, co powodowało drastyczne obniżenie poziomu życia mieszkańców wsi.

$\mathrm{Na}$ terenach okupowanych przez ZSRR już w 1939 r. wielka własność ziemska została przejęta przez państwo. Chcąc pozyskać poparcie chłopów, większość gruntów rozparcelowano, a z części utworzono sowchozy. Jednocześnie rozpoczęto walkę z bogatymi chłopami, tzw. kułakami, na których nałożono wysokie normy przymusowych dostaw artykułów 
rolnych. Przystąpiono też do kolektywizacji wsi, ale jej tempo było bardzo powolne i zostało przerwane W I94I r. przez agresję III Rzeszy na ZSRR ${ }^{24}$.

Jeszcze w okresie wojennym 22 lipca I944 r. Polski Komitet Wyzwolenia Narodowego (PKWN) (tymczasowy organ nowej komunistycznej władzy państwowej na ziemiach polskich) ogłosił Manifest, w którym zapowiedział przeprowadzenie reformy rolnej. Szczegółowe zasady reformy zostały określone we wrześniu 1944 r., a dla ziem zachodnich i północnych we wrześniu $1946 \mathrm{r}$. W ramach reformy utworzono Państwowy Fundusz Ziemi, w skład którego weszły przejęte majątki „obszarników” (o powierzchni ponad $50 \mathrm{ha}$, a w województwach poznańskim, gdańskim i śląskim - ponad too ha) oraz gospodarstwa skonfiskowane Niemcom i osobom uznanym za zdrajców narodu polskiego ${ }^{25}$. Ustalono, że ziemie te zostaną rozdzielone pomiędzy robotników rolnych, chłopów małorolnych i średniorolnych mających liczne rodziny. Łącznie przejęto 652 tys. nieruchomości rolnych (w tym prawie 3I tys. nieruchomości o powierzchni większej niż $50 \mathrm{ha}$ ), obejmujących około I3 $\mathrm{mln}$ ha ziemi (razem z lasami). Państwo z przejętej ziemi rozdzieliło mniejszą jej część między drobnych właścicieli, większą zaś pozostawiło jako rezerwę na organizowanie ośrodków kultury rolnej ${ }^{26}$.

$\mathrm{Na}$ ziemiach wchodzących w skład państwa polskiego przed rokiem 1939, do końca 1949 r. rozparcelowano 2,4 mln ha gruntów, głównie obszarniczych. Utworzono z nich 347 tys. gospodarstw oraz powiększono 254 tys. Przeciętny obszar gospodarstw nowych wyniósł 5,4 ha, a parceli powiększających istniejące gospodarstwa - I,9 ha. Na ziemiach przyłączonych do Polski w $1945 \mathrm{r}$. na cele osadnictwa rolnego przeznaczono 3,7 $\mathrm{mln}$ ha gruntów. Utworzono 467 tys. gospodarstw, o przeciętnej powierzchni 7,9 ha, wśród których dominowały parcele o obszarze od 7 do is ha. Łącznie na całym terytorium kraju rozparcelowano 6,I $\mathrm{mln}$ ha gruntów między I,I mln rodzin ${ }^{27}$. Konsekwencją parcelacji i osadnictwa była znacznie zmieniona struktura obszarowa gospodarstw. W stosunku do okresu międzywojennego wyraźnie zmniejszyła się liczba gospodarstw najmniejszych (poniżej 2 ha), a także gospodarstw o obszarze $2-5$ ha. Powiększyła się natomiast liczba i powierzchnia gospodarstw średnich i dużych ( $5-20 \mathrm{ha})$. Rezultaty reformy były różne w zależności od regionu. W najbardziej przeludnionych

\footnotetext{
24 M. Michałek, dz. cyt., s. 55-80.

25 K. Kersten, Polski Komitet Wyzwolenia Narodowego 22 VII - 3 I XII 1944, Lublin 1965, s. 36.

26 E. Grzelak, dz. cyt., s. Iıo.

27 Rolniczy Rocznik Statystyczny 1945-1965, Warszawa 1966, s. 115.
} 
województwach południowych wielkich majątków było niewiele, więc ich parcelacja nie spowodowała zmian w przeciętnej wielkości gospodarstw rolnych. We wschodniej i środkowej Polsce ziemie uzyskali robotnicy rolni i chłopi posiadający dotąd małe gospodarstwa, co w ograniczonym stopniu poprawiło strukturę agrarną tej części kraju. Na zachodzie utworzono przede wszystkim nowe gospodarstwa, które otrzymali dawni robotnicy rolni lub ludność przesiedlona z innych części kraju ${ }^{28}$. Znaczna nadwyżka ziemi oraz problemy z ich zasiedleniem pozwoliły zastosować wyższe niż $\mathrm{w}$ innych regionach normy przydziału ziemi $(7-15 \mathrm{ha})^{29}$.

W drugiej połowie lat $40 . \mathrm{XX}$ w. władze polityczne podjęły działania przebudowy polskiej wsi na wzór radziecki. Miały się one dokonać w drodze kolektywizacji, ograniczenia liczby gospodarstw indywidualnych oraz rozbudowy sektora państwowego ${ }^{30}$. Zaczęto lansować spółdzielnie produkcyjne z jednoczesną nagonką na obszarowo wielkie gospodarstwa chłopskie, zwłaszcza w latach 1953-1955. Szczególnie ostro byli zwalczani bogatsi chłopi, czyli tzw. kułacy, ogłoszeni przez partię wrogami państwa ${ }^{31}$. Równocześnie przystąpiono do tworzenia sektora państwowego, przeznaczając na ten cel Io\% ogólnego areału użytków rolnych. W I946 r. utworzono przedsiębiorstwo Państwowe Nieruchomości Ziemskie (PNZ), które miało zagospodarować opuszczone i zdewastowane majątki na obszarze ziem zachodnich i północnych ${ }^{32}$. Wkrótce rozszerzono działalność PNZ również na ziemie dawne (należące do II Rzeczypospolitej, które pozostały w granicach Polski po 1945 r.), chociaż państwo przejęło tam zdecydowanie mniej ziemi. W I946 r. z ogólnego obszaru I,6 mln ha należących do państwa, na ziemiach nowych znajdowało się aż $\mathrm{I}, 3 \mathrm{mln} \mathrm{ha}^{33}$. W kolejnych miesiącach stan posiadania PNZ zmieniał się, dynamicznie - przejmowano kolejne majątki, a inne oddawano na parcelację. Na początku I 949 r. wszystkie gospodarstwa państwowe (nieruchomości ziemskie, hodowla roślin i chów koni) połączono, tworząc Państwowe Gospodarstwa Rolne (PGR).

28 J. Bański, Historia rozwoju gospodarki rolnej na ziemiach polskich, [w:] Cztowiek i rolnictwo, red. Z. Górka, A.Zborowski, Kraków 2009, s.33-45.

29 H.Słabek, Dzieje polskiej reformy rolnej 1944-1948, Warszawa 1972, s. 20-23.

30 M. Michałek, dz. cyt., s. 70.

31 M. Nadolski, Komuniści wobec chtopów w Polsce 194I-1956. Mity irzeczywistość, Warszawa 1993, s. 203; S. Jankowiak, Wielkopolski kutak wrogiem państwa socjalistycznego, „Biuletyn Instytutu Pamięci Narodowej" 2002, nr I, s. 30.

32 P. Dziurzyński, Osadnictwo rolne na Ziemiach Odzyskanych, Warszawa 1983, s. 128.

33 W. Rogala, Dziatalność Państwowych Nieruchomości Ziemskich (1946-1949), „Rocznik Muzeum Rolnictwa w Szreniawie" 1972, t. 5. 
Weszły one na trwałe do krajobrazu polskiej wsi i stały się jednym z symboli socjalistycznych przemian w rolnictwie ${ }^{34}$.

Mimo ogromnej kampanii propagandowej w I949 r., pierwszym roku kolektywizacji, powstało tylko 243 spółdzielni skupiających zaledwie o,I\% wszystkich gospodarstw. W ocenie władz wyniki te były zbyt niskie, dlatego sięgnięto po metody administracyjne, represje polityczne, przymus fizyczny i sankcje ekonomiczne, za pomocą których zmuszano chłopów do wstępowania do spółdzielni. Do końca 1955 r. utworzono blisko ro tys. spółdzielni, które użytkowały około I,9 $\mathrm{mln}$ ha gruntów rolnych, czyli $9 \%$ powierzchni użytków rolnych w kraju ${ }^{35}$. W tym samym czasie powstało ponad 6 tys. gospodarstw państwowych obejmujących I2\% użytków rolnych, w tym dwie trzecie znajdowało się na ziemiach zachodnich i północnych ${ }^{36}$.

Równolegle z silnym popieraniem kolektywizacji od 1949 r. trwał proces osłabiania i eliminacji własności prywatnej. Gospodarstwom rodzinnym odmawiano kredytów oraz zakupu środków do produkcji, a jednocześnie obciążano obowiązkowymi świadczeniami rzeczowymi i finansowymi na rzecz uprzemysłowienia kraju. Praktycznie uniemożliwiono obrót ziemią i sztucznie utrzymywano niski poziom cen urzędowych na produkty rolne. Nastąpił upadek tysięcy gospodarstw chłopskich, połączony z ucieczką ze wsi młodych ludzi, pozbawionych perspektywy indywidualnego gospodarowania $^{37}$. Wieś została obciążona także dodatkowymi podatkami, np. obowiązkową składką na Społeczny Fundusz Rozwoju ${ }^{38}$. Rolnictwa. Następstwem forsownej kolektywizacji i działań wobec gospodarstw prywatnych było załamanie się produkcji rolnej w pierwszej połowie lat 50. XX w. W tym czasie wiele osób młodych, pozbawionych perspektywy indywidualnego gospodarowania, wyjechało ze wsi do miast. Konsekwencją prowadzonej polityki było pogorszenie struktury agrarnej gospodarstw prywatnych. Udział gospodarstw karłowatych w ogólnej ich liczbie wzrósł o ir\%, a małorolnych o $7 \%$. Jednocześnie spadł odsetek gospodarstw średniorolnych (5-20 ha) i dużych (20-50 ha) ${ }^{39}$.

34 M. Michałek, dz. cyt., s. 74-75.

35 D. Jarosz, Polityka wtadzkomunistycznych w Polsce wlatach 1948 -1956 a chtopi, Warszawa 1998.

36 M. Michałek, dz. cyt., s. 75 .

37 J. Kaliński, dz. cyt., s. 127.

38 R. Winiewska, Obciażenia podatkowe gospodarstw chtopskich w Polsce w latach 1945-1955,

Warszawa 1961, s. 44-49.

39 Rocznik Statystyczny 1957, Warszawa 1957, s. 130. 
Zmiana polityki państwa wobec rolników indywidualnych wystąpiła dopiero w 1956 r. Wówczas ograniczone zostały dostawy obowiązkowe płodów rolnych, podniesiono ceny skupu, a także złagodzono politykę podatkową i umożliwiono chłopom korzystanie z kredytów bankowych. Ustępstwa te zaowocowały nie tylko zmianą nastrojów na wsi, ale również natychmiastowym wzrostem produkcji rolnej ${ }^{40}$. Zmiana polityki rolnej państwa po 1956 r. spowodowała również rozwiązanie się większości spółdzielni produkcyjnych. W 1957 r. było ich już tylko I083. W 1959 r. utworzono Fundusz Rozwoju Rolnictwa, na który odprowadzano kwoty uzyskane z różnicy pomiędzy cenami rynkowymi a cenami płaconymi przez państwo. Służył on finansowaniu rozwoju rolnictwa, głównie jednak uspołecznionego. W tym czasie rozpoczęto również tworzenie kółek rolniczych, które dysponowały traktorami i maszynami rolniczymi, wytwarzały materiały budowlane, uczestniczyły w melioracjach i przetwórstwie rolno-spożywczym. Początkowo, po doświadczeniach kolektywizacji lat 50., chłopi niechętnie wstępowali do kółek rolniczych. Z czasem jednak zaczęli dostrzegać coraz więcej korzyści z członkostwa w tej formie organizacyjnej i powszechnie do nich wstępowali ${ }^{41}$.

W latach 60. Xx w., charakteryzujących się niekonsekwentną polityką agrarną, nieco zmniejszył się udział gospodarstw małorolnych, ale powiększył się udział gospodarstw karłowatych, przekraczając 33\% ogółu gospodarstw $^{42}$. W kolejnym dziesięcioleciu w wyniku pogarszającej się sytuacji w kraju odnotowano dalsze zmiany polityki państwa wobec rolników indywidualnych. W 1972 r. zniesiono dostawy obowiązkowe. Ponadto, rolnicy mogli korzystać z kredytów inwestycyjnych. Priorytetem w zaopatrzeniu nadal były gospodarstwa państwowe, ale rolnicy indywidualni w zamian za umowy kontraktacyjne mogli uzyskać przydziały deficytowych maszyn, narzędzi czy nawozów ${ }^{43}$. Umożliwiono również powiększanie gospodarstw do 8 ha, a nawet 20 ha, jednocześnie zabraniając podziałów na gospodarstwa mniejsze niż 8 ha użytków rolnych, co miało zapobiec ich nadmiernemu rozdrobnieniu. Po raz pierwszy rolnicy i ich rodziny zostali objęci bezpłatną opieką zdrowotną. Zostało im również przyznane prawo do świadczeń emerytalnych, chociaż początkowo wyłącznie w zamian za przekazanie gospodarstwa na własność skarbu państwa. W 1980 r. 74,8\% użytków rolnych

\footnotetext{
40 M. Michałek, dz. cyt., s. 72.

41 J. Bański, dz. cyt., s. 42.

42 J. Kaliński, dz. cyt., s. 139 .

43 M. Michałek, dz. cyt., s. 77 .
} 
ELŻBIETA JADWIGA SZYMAŃSKA Zmiany struktury agrarnej na polskiej wsi w latach 1918-2018

тАв. 3 Struktura agrarna rolnictwa indywidualnego w latach 1950-1980

\begin{tabular}{|c|c|c|c|c|c|}
\hline \multirow{2}{*}{ Wyszczególnienie } & \multicolumn{4}{|c|}{ Lata } & \\
\hline & 1950 & 1960 & 1970 & 1980 & 1985 \\
\hline $\begin{array}{r}\text { Liczba gospodarstw } \\
\text { ogółem [tys.] }\end{array}$ & 2762 & 2937 & 2935 & 2390 & 2296 \\
\hline
\end{tabular}

Struktura gospodarstw [\%]:

2-5 ha

5-7 ha

7-10 ha

10-15 ha

15 ha i więcej

Średnia powierzchnia gospodarstwa [ha]

Odsetek powierzchni gruntów w gospodarstwach powyżej 10 ha [\%]
15,0

35,9

17,3

18,0

8,9

4,9

5,3

33,3
17,8

37,2

16,2

15,7

9,7

3,4

5,2

33,1

35,0

35,0

15,8

15,5

10,8
18,7

18,8

37,0

35,5

15,3

14,8

14,7

14,6

10,0

10,8

6,0

36,3

Źródło: A. Woś, Prognoza przekształceń strukturalnych polskiego rolnictwa do 2020 , Warszawa 1996; S.W. Kłopot, Struktura agrarna indywidualnego rolnictwa w latach 1945-20I0, „Annales Universitatis Mariae Curie-Skłodowska” 20II, VOL. XXXVI, z. 2, Sectio I, s. 96; Rocznik statystyczny 1992, Warszawa 1992, s.310.

należało do indywidualnych gospodarstw rolnych, 19,8\% do PGR rozmieszczonych głównie na północy i zachodzie kraju, z kolei 4,०\% do spółdzielni produkcyjnych a I, $4 \%$ do kółek rolniczych ${ }^{44}$.

44 E. Grzelak, dz. cyt., s. 24. 
W wyniku różnokierunkowych zmian w polityce agrarnej przeciętna wielkość gospodarstwa chłopskiego w I980 r. w stosunku do 1950 r. zwiększyła się tylko o o,3 ha i wynosiła 5,6 ha. Wynikało to ze wzrostu liczby gospodarstw najmniejszych. Odsetek gospodarstw do 2 ha zwiększył się Z I $5,0 \%$ do $18,7 \%$, a od 2 do 5 ha z 35,9\% do 37,0\%. Udzial gospodarstw o obszarze powyżej io ha stanowił tylko I 4,3\%, ale obejmował $35,7 \%$ powierzchni UR (tab.3). W latach 1970-1985 wystąpiła znaczna redukcja gospodarstw rolnych, których liczba zmniejszyła się o 639 tys. Zwiększył się natomiast odsetek gospodarstw większych, powyżej ro ha. W tej sytuacji średnia powierzchnia gospodarstwa w 1985 roku wyniosła 6,0 ha UR.

Udział poszczególnych form społeczno-gospodarczych w użytkowaniu ziemi rolniczej po II wojnie światowej przedstawiono w tabeli 4. W I946 r. udział gospodarstw państwowych w użytkowaniu ziemi rolniczej był niewielki. W kolejnych latach sukcesywnie wzrastał, dochodząc do maksymalnego poziomu w I980 r., kiedy wynosił 19,5\%. Z kolei udział spółdzielni produkcyjnych w 1950 r. stanowił tylko o,8\%. W i970 r. odsetek tej formy gospodarowania zwiększył się do I,3\%, a w I980 r. stanowił 4,0\%. Udział gospodarstw indywidulanych $\mathrm{w}$ analizowanym okresie wykazywał tendencję spadkową. W I946 r. taka forma gospodarstw obejmowała 93,2\%, a w 1980 r. $74,5 \%$ powierzchni UR.

TAB. 4 Udział sektorów w użytkowaniu ziemi według stanu w czerwcu w latach $1946-1990$

\begin{tabular}{|c|c|c|c|c|}
\hline \multirow[b]{2}{*}{ Lata } & \multirow{2}{*}{$\begin{array}{c}\text { Powierzchnia UR } \\
\text { [tys. ha] }\end{array}$} & \multicolumn{3}{|c|}{ Udział sektorów [\%] } \\
\hline & & $\begin{array}{c}\text { Gospodarstwa } \\
\text { państwowe }\end{array}$ & $\begin{array}{l}\text { Spółdzielnie } \\
\text { produkcyjne }\end{array}$ & $\begin{array}{l}\text { Gospodarstwa } \\
\text { indywidualne }\end{array}$ \\
\hline 1946 & 20440,02 & 6,8 & - & 93,2 \\
\hline 1950 & 20440,02 & 9,6 & 0,8 & 89,6 \\
\hline 1960 & 20402,80 & 11,9 & 1,2 & 86,9 \\
\hline 1970 & 19543,20 & 15,3 & 1,3 & 83,4 \\
\hline 1980 & 18846,90 & 19,5 & 4,0 & 74,5 \\
\hline 1990 & 18720,00 & 18,7 & 4,5 & 76,8 \\
\hline
\end{tabular}

Źródło: Rocznik statystyczny 1957, Warszawa 1957, s. 124; tamże, 196I, Warszawa 1961, s. 177; tamże, 1971, Warszawa 1971, s. 273; tamże, 1992, Warszawa 1992, s. 309; C. Leszczyńska, Polska 1918-2018. Historia Polski w liczbach, t. 5. Warszawa 2018, s. 195. Por.: S.W. Kłopot, Struktura agrarna indywidualnego rolnictwa w latach 1945-2010, „Annales Universitatis Mariae Curie-Skłodowska" 20II, vol. XxxvI, z. 2, Sectio I, s. 96. 
W I989 r. przejście od gospodarki centralnie sterowanej do rynkowej wymusiło dostosowania struktury własnościowej i obszarowej rolnictwa do nowych uwarunkowań. W okresie transformacji ustrojowej szczególne znaczenie dla rolnictwa miało: uwolnienie mechanizmu rynkowego (liberalizacja handlu) i tym samym wycofanie się państwa z polityki nakazowo-rozdzielczej, kurs na likwidację rolnictwa uspołecznionego (zwłaszcza państwowego - PGR), likwidacja wielu instytucji rolnych, przy jednoczesnym tworzeniu nowych, prywatyzacja otoczenia rolnictwa (przemysł środków produkcji dla rolnictwa, przemysł rolno-spożywczy i obrót rolny), ograniczenie rynku pracy dla tzw. chłoporobotników oraz rozwinięcie polityki socjalnej wobec ludności rolniczej45. W i990 r. gospodarstwa o powierzchni poniżej 2 ha użytków rolnych stanowiły $17,7 \%$, a od 2,0 do 9,99 ha aż $64,9 \%$. Z kolei udział gospodarstw powyżej is ha wynosił tylko $6, \mathrm{I} \%$ (tab. 5 ).

TAB. 5 Struktura obszarowa gospodarstw indywidualnych w latach $1990-2004$

\begin{tabular}{|c|c|c|c|c|}
\hline Grupy gospodarstw & 1990 & 1995 & 2000 & 2004 \\
\hline $1,01-1,99$ ha & 17,7 & 20,9 & 23,8 & 26,1 \\
\hline $2,00-4,99 \mathrm{ha}$ & 35,1 & 33,7 & 32,6 & 32,1 \\
\hline $5,00-9,99$ ha & 29,8 & 26,7 & 23,8 & 21,8 \\
\hline $10,00-14,99$ ha & 11,3 & 10,7 & 9,9 & 9,6 \\
\hline $15,00-19,99 \mathrm{ha}$ & 6,1 & 4,4 & 4,5 & 4,3 \\
\hline 20,00 ha i więcej & $\mathrm{x}$ & 3,6 & 5,4 & 6,1 \\
\hline
\end{tabular}

Źródło: J. Kaliński, Przemiany struktury obszarowej gospodarstw chtopskich w Polsce po 1918 roku, „Kwartalnik Kolegium Ekonomiczno-Społecznego Studia i Prace. Szkoła Główna Handlowa” 2018, nr 3, s. 134; Rocznik statystyczny 2005, Warszawa 2005 , s. 459 .

Zmiana systemu politycznego i gospodarczego w Polsce w i989 r. ujawniła strukturalne słabości gospodarstw państwowych. Wystąpiła konieczność przekształceń własnościowych w tym sektorze. Dotychczasowe struktury

45 J.S.Zegar, Polskie rolnictwo w okresie dwóch przetomów - transformacji ustrojoweji integracji europejskiej, „Nierówności Społeczne a Wzrost Gospodarczy” 2015, nr 4I, s. 148-160. 
okazały się niewydolne w gospodarce rynkowej. Wśród istotnych przesłanek skłaniających do przekształceń własnościowych w rolnictwie państwowym należy wskazać: aspekty prawne (niejasna rola właściciela państwowego), ekonomiczne i organizacyjne (niska sprawność ekonomiczna i organizacyjna), zagrożenie korupcją i dziką prywatyzację ${ }^{46}$. Ramy prawne prywatyzacji gospodarstw uspołecznionych stworzyła ustawa z I99i r. o gospodarowaniu nieruchomościami rolnymi Skarbu Państwa ${ }^{47}$. Przekształcenie spółdzielni produkcyjnych miało charakter formalny, gdyż zgodnie z prawem stawały się one częścią sektora prywatnego. Z kolei państwowe gospodarstwa rolne zostały zlikwidowane, a ich majątek trafił do Zasobów Własności Rolnej Skarbu Państwa (ZWRSP) zarządzanych przez Agencję Własności Rolnej Skarbu Państwa (AWRSP). Na bazie 1666 zlikwidowanych PGR utworzono 1794 Gospodarstwa Rolne Skarbu Państwa, którymi zarządzali tymczasowi zarządcy i administratorzy. Następnie gospodarstwa te poddano restrukturyzacji, wydzielając grunty do sprzedaży lub dzierżawy rolnikom indywidualnym na powiększenie ich gospodarstw i tworząc jednostki zorganizowane w celu wykorzystania istniejących zasobów budowlanych i przekazywania ich $w$ formie dzierżawy, a następnie sprzedaży różnym podmiotom, $w$ tym spółkom tworzonym przez byłych pracowników gospodarstw państwowych ${ }^{48}$. Proces likwidacji państwowych przedsiębiorstw rolnych zakończył się w $1995 \mathrm{r}$. i miał rozległe skutki o charakterze społecznym i ekonomicznym, powodując wysoki poziom bezrobocia, stagnację życia i rozwój ubóstwa w regionach popegeerowskich ${ }^{49}$.

Do 2004 r. do ZWRSP przejęto 4,7 mln ha gruntów, z czego sprzedano I,5 mln ha, czyli 31\% przejętej ziemi. Zwykle sprzedawano małe działki, liczące średnio 7,6 ha. Większość gruntów ZWRSP została wydzierżawiona, co zapoczątkowało proces powstawania prywatnych wielkoobszarowych gospodarstw rolnych. W rezultacie niedostatecznych wyników sprzedaży w 2004 r. jeszcze I2,3\% użytków rolnych znajdowało się we władaniu publicznym (własność państwowa, samorządowa i mieszana). Jednak

46 H. Runowski, W.Ziętara, Stan dotychczasowy i rekomendacje na przysztość w procesie przeksztatceń wtasnościowych, [w:] Przeksztatcenia wtasnościowe w rolnictwie - Io lat doświadczeń, Warszawa 2002, s. 43-70.

47 Dziennik Ustaw Rzeczypospolitej Polskiej (dalej: Dz.U.) 1991, nr 107, poz. 464, Ustawa z dnia I9 października 1991 r. o gospodarowaniu nieruchomościami rolnymi Skarbu Państwa oraz o zmianie niektórych ustaw.

48 W.Ziętara, Spoteczny czy ekonomiczny charakter reform rolnych $w$ Polsce w okresie międzyipowojennym, „Roczniki Naukowe Ekonomii Rolnictwa i Rozwoju Obszarów Wiejskich” 2015 , t. IO2, z. I, S.3I-45.

49 J. Bański, dz. cyt., s. 4I. 
w porównaniu z I990 r. zwiększył się udział własności indywidualnej w ogólnym zasobie użytków rolnych z 73,3\% do $87,9 \%$ w 2002 r. $^{50} \mathrm{Zda}$ niem Józefa St. Zegara, taka sytuacja była właściwa w kontekście znaczenia rodzinnego modelu gospodarowania w rolnictwie w płaszczyźnie stabilizacji społecznej i politycznej państwa oraz sprawiedliwości ekonomicznej. W latach 1990-2002 odsetek użytków rolnych będących w posiadaniu gospodarstw państwowych zmniejszył się z I 8,6\% do 5,4\%, natomiast udział spółdzielni produkcyjnych uległ ograniczeniu z 4,I\% do I,9\% UR.

TAB. 6 Udział sektorów w użytkowaniu ziemi według stanu w czerwcu w latach $1990-2002$

\begin{tabular}{|c|c|c|c|c|}
\hline \multirow[b]{2}{*}{ Lata } & \multirow[b]{2}{*}{$\begin{array}{l}\text { Powierzchnia UR } \\
\text { [tys. ha] }\end{array}$} & \multicolumn{3}{|c|}{ Udział sektorów [\%] } \\
\hline & & $\begin{array}{c}\text { Gospodarstwa } \\
\text { państwowe }\end{array}$ & $\begin{array}{l}\text { Spółdzielnie } \\
\text { produkcyjne }\end{array}$ & $\begin{array}{l}\text { Gospodarstwa } \\
\text { indywidualne }\end{array}$ \\
\hline 1990 & 18720,00 & 19,9 & 4,0 & 76,0 \\
\hline 1995 & 17934,00 & 10,2 & 2,9 & 81,6 \\
\hline 2000 & 17812,00 & 7,8 & 2,0 & 83,9 \\
\hline 2002 & 16899,00 & 5,5 & 1,9 & 87,9 \\
\hline
\end{tabular}

Źródło: F. Kapusta, Drogi i bezdroża gospodarstw rodzinnych w Polsce, „Problemy Drobnych Gospodarstw Rolnych” 2013 , nr 2, s. 48 .

W latach 1990-2004, mimo różnokierunkowych tendencji w strukturze obszarowej gospodarstw, następował proces koncentracji ziemi. Ogólna liczba gospodarstw zmniejszyła się z 2,I mln do I,8 mln, czyli o I3\%, a ich przeciętna powierzchnia zwiększyła się z 7,r ha do 8,4 ha (o I8\%). W 2004 r. odsetek gospodarstw najmniejszych o powierzchni do I,99 ha zwiększył się do 26,1\%, a udział podmiotów większych o powierzchni od 2,0 do 9,99 ha zmniejszył się do 53,9\%. Podobnie zwiększył się udział gospodarstw największych o powierzchni powyżej is ha do I0,4\%, głównie na północy i zachodzie Polski. Wraz ze zmianą struktury gospodarstw dokonywały się przeobrażenia w strukturze własności ziemi rolnej w Polsce (tab. 6). Zmniejszał się udział gospodarstw państwowych i spółdzielni produkcyjnych w użytkowaniu ziemi rolnej i jednocześnie zwiększało się znaczenie własności prywatnej. W 2002 r. gospodarstwa indywidualne posiadały $87,9 \%$ UR w kraju.

50 J. Kaliński, Transformacja gospodarki polskiej w latach 1989-2004, Warszawa 2009, s. 63, 102. 
Przed 2004 r. przemiany w strukturze obszarowej gospodarstw, niezbędne do powiększenia i zracjonalizowania produkcji rolnej, ciągle znajdowały się jednak w stadium początkowym. Wymagały one różnokierunkowych działań w sferze finansowania, rozwoju usług i handlu na wsi, umocnienia samorządu wiejskiego oraz dostosowania produkcji przemysłowej do nowych potrzeb produkcyjnych rolnictwa i przetwórstwa płodów rolnych. Niezbędne były także rozstrzygnięcia o charakterze politycznym co do przyszłego kształtu polskiego rolnictwa ${ }^{51}$.

\section{Zmiany struktury agrarnej w Polsce po 2004 r.}

W ramach przygotowań do wstąpienia Polski do Unii Europejskiej przyjęto lub znowelizowano wiele aktów prawnych w odniesieniu do rolnictwa i jego struktury. Zasadnicze znaczenie miała ustawa z 2003 r. o kształtowaniu ustroju rolnego ${ }^{52}$. Jej celem była zgodna z postulatami UE poprawa struktury obszarowej gospodarstw rolnych i przeciwdziałanie nadmiernej koncentracji nieruchomości rolnych, na co pozwalały regulacje prawne z początku lat 90. XX w. W ustawie przyjęto, że nabywcą nieruchomości rolnej może być wyłącznie rolnik indywidualny, a powierzchnia nabywanej nieruchomości rolnej nie może przekraczać powierzchni 300 ha użytków rolnych. W tym zakresie uwzględniono jednak kilka odstępstw, jeśli zakup ziemi był realizowany przez osobę bliską zbywcy, jednostkę samorządu terytorialnego, Skarb Państwa czy też inne podmioty wymienione w ustawie. Na mocy ustawy zlikwidowano AWrsp, powołując jednocześnie Agencję Nieruchomości Rolnych (ANR), z zadaniem tworzenia oraz powiększania gospodarstw rodzinnych. ANR wyposażono w prawo pierwokupu dające możliwość sprawowania kontroli nad częścią obrotu nieruchomościami rolnymi na rynku. Miało to prowadzić do powiększania gospodarstw rozwojowych i będących w rękach młodych, wykształconych rolników ${ }^{53}$.

Wraz z przystąpieniem Polski do uE polskie rolnictwo zostało objęte szeregiem instrumentów Wspólnej Polityki Rolnej, co stworzyło możliwości szybszego rozwoju obszarów wiejskich. Ich zestaw był bardzo różnorodny, a oddziaływanie na przemiany agrarne zróżnicowane. Bezpośredni wpływ

51 Tenże, Przemiany..., s. I21-I43.

52 Dz.U. 2003, nr 64, poz. 592, Ustawa z dnia II kwietnia 2003 r. o kształtowaniu ustroju rolnego.

53 B. Mickiewicz, Wptyw regulacji prawnych na zmiane struktury agrarnej $w$ Polsce po Ig9I roku, „Roczniki Naukowe Stowarzyszenia Ekonomistów Rolnictwa i Agrobiznesu” 2013 , t. XV, z. I, s. 143 . 
na strukturę obszarową miały renty strukturalne uwzględnione w Planie Rozwoju Obszarów Wiejskich na lata 2004-2006 oraz na lata 2007-2013. Ich odziaływanie wynikało z mechanizmu funkcjonowania, który polegał na zaprzestaniu działalności rolniczej przez osoby w wieku przedemerytalnym i przekazaniu ziemi rolnej na powiększenie innego gospodarstwa lub na rzecz następcy nieprowadzącego wcześniej działalności rolniczej. W latach 2004-20I3 w ramach tego działania przekazano około 73,5 tys. gospodarstw rolnych (w tym 52,I\% na powiększenie innych gospodarstw) o łącznej powierzchni 7I8,9 tys. ha UR (w tym na powiększenie innych gospodarstw 50,7\%). Ze względu na niewielką skalę oddziaływania programu rent strukturalnych (objęto nim niespełna $5 \%$ gospodarstw i niewiele więcej UR) oraz przekazywanie posiadanego majątku produkcyjnego następcom $(49,3 \%)$, co praktycznie oznaczało kontynuację prowadzenia gospodarstwa już istniejącego, wpływ instrumentu rent strukturalnych na proefektywnościową przebudowę struktury obszarowej był relatywnie niewielki. Potencjał tego działania nie został optymalnie wykorzystany, również z powodu dość łagodnych kryteriów otrzymania wsparcia ${ }^{54}$.

Z badań Dariusza Żmii wynika, że do zwiększania powierzchni gospodarstw najczęściej skłaniało rolników realizowanie projektów inwestycyjnych w ramach działania unijnego programu „Modernizacja gospodarstw rolnych” PROW 2007-2013, a także działania „Wspieranie gospodarstw niskotowarowych" realizowanego w ramach PROW 2004-2006 $6^{55}$. Na wzrost posiadanego areału wpływały także inne działania, takie jak program „Różnicowanie w kierunku działalności nierolniczej”, który realizowany był w ramach PROW 2007-2013, a także działania „Ułatwienie startu młodym rolnikom” oraz „Inwestycje w gospodarstwach rolnych”, które znalazły się w Sektorowym Programie Operacyjnym „Restrukturyzacja i modernizacja sektora żywnościowego oraz rozwój obszarów wiejskich 2004-2006" (sPO „Restrukturyzacja”). W mniejszym stopniu na wzrost powierzchni upraw wpłynęło działanie „Wspieranie gospodarstw niskotowarowych”, które realizowane było w ramach PROW 2004-2006, a także działania „Różnicowanie w kierunku działalności nierolniczej” oraz „Przywracanie potencjału produkcji zniszczonego w wyniku wystąpienia klęsk żywiołowych”, uwzględnione w PROw 2007-2013. Ze względu na ograniczoną

54 B. Karwat-Woźniak, P. Chmieliński, Przemiany w strukturze agrarnejpolskiego rolnictwa i wptyw wybranych instrumentów WPR na te procesy, „Prace Naukowe Uniwersytetu Ekonomicznego we Wrocławiu” 2016, nr 450, s. 272-286.

55 D. Żmija, Wptyw wybranych instrumentów wspólnejpolityki rolnej na zmiany w zasobach ziemi matych gospodarstw rolnych z województwa matopolskiego, „Roczniki Naukowe Stowarzyszenia Ekonomistów Rolnictwa i Agrobiznesu” 2017, t. XIX, z.3, s.345-350. 
liczbę beneficjentów zakres oddziaływania tych instrumentów na strukturę agrarną gospodarstw rolniczych w Polsce był jednak mały.

Najpowszechniejszym instrumentem WPR, z jakiego korzystają polscy rolnicy, są dopłaty bezpośrednie, które w swoich założeniach mają uzupełniać dochody rolnicze. Całkowite oderwanie jednolitej płatności obszarowej (JPO) od produkcji i bezpośrednie jej powiązanie z obszarem spowodowało dwojaki sposób oddziaływania dopłat bezpośrednich na przemiany struktury obszarowej. Z jednej strony, stymulują one procesy koncentracji, ponieważ wzrost powierzchni gospodarstwa wiąże się z uzyskaniem większych dopłat, ale z drugiej strony powodują, że właściciele mniejszych gospodarstw nie pozbywają się gruntów, ponieważ mają możliwość uzyskania wsparcia finansowego. Na utrzymywanie małych gospodarstw wpływ miała również pomoc skierowana w ramach działania "Wspieranie gospodarstw niskotowarowych", ponieważ kryteria uzyskania środków były relatywnie liberalne ${ }^{56}$. W związku z tym struktura agrarna w Polsce nadal jest bardzo rozdrobniona i silnie spolaryzowana.

Przepływy finansowe do rolnictwa w formie płatności bezpośrednich i programów rozwoju obszarów wiejskich wywołały szereg zmian w zasobach i rozdysponowaniu czynników produkcji w rolnictwie. Istotnym elementem stała się większa stabilizacja i przewidywalność polityki w okresach budżetowych UE oraz dostęp do jednolitego rynku europejskiego ${ }^{57}$.

W 2010 r. w Polsce funkcjonowało blisko I,5 mln gospodarstw rolnych użytkujących około I4, $4 \mathrm{mln}$ ha gruntów rolnych. W porównaniu do roku 2003 liczba gospodarstw rolnych w Polsce zmalała o 646 tys. Związane to było przede wszystkim ze spadkiem liczby gospodarstw najmniejszych o powierzchni poniżej 2 ha użytków rolnych. Ich liczba zmniejszyła się prawie trzykrotnie (o ponad 576 tys.), a powierzchnia gruntów rolnych będących w posiadaniu tych gospodarstw zmalała o bisko 245 tys. ha. Takie same kierunki przeobrażeń strukturalnych zaobserwowano w gospodarstwach sklasyfikowanych we wszystkich grupach obszarowych o powierzchni poniżej 20 ha UR. Wzrost liczby gospodarstw i powierzchni użytków rolnych obserwowany był jedynie w grupach gospodarstw o powierzchni większej niż 30 ha. Łączna liczba takich gospodarstw w latach 2003-2010 wzrosła o około I4 tys., a powierzchnia użytków rolnych będących w posiadaniu tych gospodarstw uległa zwiększeniu o ponad 980 tys. ha. W gospodarstwach o powierzchni powyżej 30 ha UR w $2010 \mathrm{r}$. znajdowało się prawie

56 B. Karwat-Woźniak, P. Chmieliński, dz. cyt., s. 284.

$57 \mathrm{M}$. Wigier, Polityka rolna i zmiany strukturalne $w$ rolnictwie polskim po akcesji do UE, „Prace Naukowe Uniwersytetu Ekonomicznego we Wrocławiu” 2014, nr 360, s. 63-71. 
TAB. 7 Struktura gospodarstw rolnych w Polsce w latach 2010-2017 (w \%)

\begin{tabular}{|c|c|c|c|c|c|c|c|c|}
\hline \multirow[b]{2}{*}{ Lata } & \multicolumn{8}{|c|}{ Obszar gospodarstw } \\
\hline & $\begin{array}{l}\frac{\pi}{5} \\
\text { 용 }\end{array}$ & $\begin{array}{l}\frac{\pi}{5} \\
\text { م్ } \\
\frac{1}{1} \\
5 \\
-\end{array}$ & 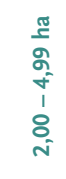 & 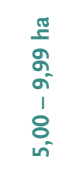 & 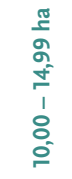 & $\begin{array}{l}\frac{\pi}{2} \\
\Omega \\
\sigma \\
\sigma \\
1 \\
8 \\
8 \\
\text { ம் }\end{array}$ & 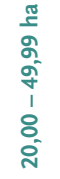 & 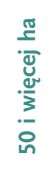 \\
\hline 2010 & 1,6 & 19,9 & 32,6 & 22,9 & 10 & 4,8 & 6,4 & 1,8 \\
\hline 2011 & 2,3 & 22,8 & 32,9 & 20,4 & 9,6 & 4,5 & 5,9 & 1,6 \\
\hline 2012 & 1,5 & 19,4 & 31,9 & 23,6 & 9,7 & 5,0 & 6,9 & 2,0 \\
\hline 2013 & 2,4 & 19,4 & 31,9 & 22,1 & 9,9 & 4,9 & 7,2 & 2,2 \\
\hline 2014 & 2,2 & 18,5 & 32,4 & 21,9 & 10,4 & 5,0 & 7,3 & 2,3 \\
\hline 2015 & 2,0 & 18,0 & 32,2 & 22,9 & 10,3 & 5,1 & 7,2 & 2,3 \\
\hline 2016 & 1,6 & 19,2 & 33,1 & 22,0 & 9,7 & 4,7 & 7,2 & 2,5 \\
\hline 2017 & 1,5 & 18,7 & 32 & 22,5 & 10,1 & 5,0 & 7,7 & 2,5 \\
\hline 2018 & 1,9 & 20,0 & 31,5 & 22,0 & 0,9 & 4,9 & 7,4 & 2,4 \\
\hline
\end{tabular}

Źródło: Rocznik statystyczny 2013, Warszawa 2013, s. 473; tamże, 2015, Warszawa 2015, s. 472; tamże, 2017, Warszawa 2017, s. 471; tamże, 2019, Warszawa 2019, s. 470 .

$40 \%$ wszystkich użytków rolnych ${ }^{58}$. Dzięki temu zwiększyło się tempo pozytywnych zmian zachodzących w strukturze agrarnej kraju. Wzrastać zaczęła liczba i powierzchnia gospodarstw średnich i dużych, co pozwoliło na poprawę efektywności produkcji rolnej i sprzyjało procesom modernizacyjnym w rolnictwie.

Od 2010 r. Główny Urząd Statystyczny wprowadził nową definicję gospodarstwa rolnego. W efekcie jej zastosowania status gospodarstwa rolnego utraciły wszystkie gospodarstwa faktycznie nieprowadzące działalności rolniczej oraz gospodarstwa o obszarze poniżej I ha UR (w tym nieposiadające użytków rolnych) należące do osób fizycznych i prowadzące taką

58 E. Szuba, W. Poczta, Efekty integracji Polskiz Unia Europejska w sektorze rolnym. Referat wygtoszony na IX Kongresie Ekonomistów Polskich, 28-29 listopada 2013 r., Warszawa 2013. 
działalność, ale poniżej określonych progów ${ }^{59}$. Mimo to, w latach 20I0-20II liczba gospodarstw rolnych w Polsce zwiększyła się z I,5I mln do I,66 mln, czyli o 9,8\%. Wiązało się to głównie ze zwiększeniem liczby gospodarstw najmniejszych od I,OI do I,99 ha (o 25,6\%) oraz podmiotów o powierzchni od 2 ha do 4,9 ha (o II,4\%) (tab. 7).Zmniejszyła się natomiast liczba gospodarstw o powierzchni od 5 do 9,99 ha (o 2,4\%) oraz powyżej 50 ha (o I,8\%).

W celu poprawy struktury agrarnej polskich gospodarstw w $20 \mathrm{II}$ r. wprowadzono ustawę o zmianie ustawy o gospodarowaniu nieruchomościami rolnymi Skarbu Państwa z 199I r., która miała na celu zwiększenie liczebności dużych gospodarstw indywidualnych ${ }^{60}$. Ustawa zdecydowanie ograniczyła dzierżawę gruntów przez ich wykup przez dzierżawców lub sprzedaż rolnikom indywidualnym w celu powiększenia powierzchni gospodarstw. W latach 20II-20I5 odnotowano tendencję spadkową w zakresie liczby gospodarstw, głównie mniejszych o powierzchni od I,or do 4,99 ha. Odmienna sytuacja wystąpiła w zakresie gospodarstw o powierzchni 20 ha i więcej, których liczba zwiększyła się o 8,5\%. W 2016 r. liczba gospodarstw ogólem zwiększyła się o I055, a wynikało to głównie ze zwiększenia liczby gospodarstw o powierzchni od I,OI do 4,99 ha oraz dużych o obszarze 50 ha i więcej.

Dnia I 4 IV 2016 r. weszła w życie Ustawa o wstrzymaniu sprzedaży nieruchomości Zasobu Własności Rolnej Skarbu Państwa oraz o zmianie niektórych ustaw, która miała na celu zahamowanie tendencji zmniejszania powierzchni gruntów rolnych (ze względu na spekulowanie ziemią przeznaczaną na cele nierolnicze), poprawę struktury obszarowej w Polsce i ochronę rodzinnych gospodarstw rolnych ${ }^{61}$. Jej zadaniem było także ograniczenie sprzedaży ziemi rolnej cudzoziemcom pochodzącym z państw członkowskich UE po zakończeniu okresu przejściowego. Zakładano przy tym, że zmiany przyczynią się do zahamowania wzrostu i ustabilizowania cen gruntów rolnych na poziomie, który nie będzie utrudniał powiększania powierzchni gospodarstw rolnych ze względu na ograniczoną zdolność nabywczą rolników w zakresie zakupu ziemi. W praktyce zaobserwowano jednak zdecydowane ograniczenie handlu nieruchomościami rolnymi ${ }^{62}$.

59 W.Dzun, Gospodarstwa rolne o obszarze do I ha w procesie przemian systemowych $i$ integracji z UE, „Wieś i Rolnictwo” 2017, nr I (174), s. 23-48.

60 Dz.U. 2011, nr 233, poz. 1382, Ustawa z dnia 16 września 20I r. o zmianie ustawy o gospodarowaniu nieruchomościami rolnymi Skarbu Państwa oraz o zmianie niektórych innych ustaw.

61 Tamże, 2016, poz. 585, Ustawa z dnia I4 kwietnia 2016 r. o wstrzymaniu sprzedaży nieruchomości Zasobu Własności Rolnej Skarbu Państwa oraz o zmianie niektórych ustaw.

62 E. Szymańska, J. May, Structural changes in the agriculture in Poland in the years 1990-2016, „Agrarna Ekonomika” 2018, t. II, z.3/4, s. 67-75. 
Obecnie w polskim rolnictwie wciąż dominują gospodarstwa małe, a odsetek gospodarstw dużych o powierzchni 50 ha i więcej w 2018 r. stanowił tylko $2,4 \%$. Średnia powierzchnia gospodarstwa rolnego zwiększyła się nieznacznie i wynosiła ı, 8 ha. Z danych wynika, że gospodarstwa rolne bardzo powoli zwiększają podstawowy zasób produkcyjny, jakim jest ziemia. Małe gospodarstwa rolne nie są bowiem zdolne do odtwarzania majątku produkcyjnego i nie są w stanie przejmować ziemi od sąsiadów rezygnujących z gospodarowania ${ }^{63}$. W przypadku większych gospodarstw o powierzchni powyżej 20 ha, występuje tendencja do akumulowania użytków rolnych. Ze względu na większy potencjał ekonomiczny są one zdolne do zakupu kolejnych gruntów na powiększenie powierzchni gospodarstw.

\section{Podsumowanie i wnioski}

W latach 19I8-20I8 wystąpiły znaczne przeobrażenia w strukturze agrarnej polskiego rolnictwa. W poszczególnych okresach historycznych były determinowane różnymi czynnikami o charakterze politycznym, ekonomicznym i społecznym. W związku z tym ich charakter i kierunek zmieniał się w czasie. Największy wpływ na zróżnicowanie struktury własnościowej i obszarowej miała przynależność ziem polskich do różnych państw zaborczych w XIX w. oraz przeprowadzone wtedy uwłaszczenie chłopów. Pomimo reform podjętych w latach międzywojennych struktura agrarna w tym okresie nie uległa większym przemianom. Obok siebie funkcjonowały duże gospodarstwa obszarnicze i bardzo małe będące własnością chłopów. Szczególnie uciążliwe dla wsi było rosnące przeludnienie agrarne oraz nieopłacalność produkcji w gospodarstwach małorolnych.

W okresie gospodarki centralnie sterowanej naczelnym celem polityki rolnej było pełne uspołecznienie rolnictwa poprzez tworzenie spółdzielni rolniczych i państwowych gospodarstw rolnych. Równolegle z silnym popieraniem kolektywizacji od 1949 r. trwał proces osłabiania i eliminacji własności prywatnej. Konsekwencją prowadzonej polityki było pogorszenie struktury agrarnej gospodarstw prywatnych. Zmiana polityki państwa wobec rolników indywidualnych wystąpiła dopiero w 1956 r. po załamaniu się produkcji rolnej. Kolejne kryzysy ekonomiczne i polityczne powodowały korekty w polityce rolnej państwa systematycznie zwiększające swobodę gospodarowania indywidualnych gospodarstw rolnych. W strukturze gospodarstw indywidualnych w tym okresie dominowały małe podmioty

63 J. Kuś, M. Matyka, Zmiany organizacyjne w polskim rolnictwie w ostatnim Io-leciu na tle rolnictwa UE, „Zagadnienia Ekonomiki Rolnej” 2014, nr 4 (34I), s. 50-67. 
o powierzchni do 5 ha użytków rolnych. Z kolei odsetek gospodarstw powyżej io ha UR nie przekraczał $15 \%$.

Przejście od gospodarki centralnie sterowanej do rynkowej wymusiło dostosowania struktury własnościowej i obszarowej rolnictwa do nowych uwarunkowań. W okresie transformacji ustrojowej szczególne znaczenie dla rolnictwa miało uwolnienie mechanizmu rynkowego oraz likwidacja rolnictwa uspołecznionego. Spółdzielnie produkcyjne zgodnie z prawem stawały się częścią sektora prywatnego, natomiast państwowe gospodarstwa rolne poddano likwidacji wydzielając grunty do sprzedaży lub dzierżawy różnym podmiotom, w tym rolnikom indywidualnym oraz spółkom tworzonym przez byłych pracowników gospodarstw państwowych. W latach 1990-2004, mimo różnokierunkowych tendencji w strukturze obszarowej gospodarstw, następował proces koncentracji ziemi. Ogólna liczba gospodarstw zmniejszyła się z 2,I mln do I, $8 \mathrm{mln}$, a ich przeciętna powierzchnia zwiększyła się z 7,I ha do 8,4 ha. Udział powierzchni UR będących w posiadaniu gospodarstw indywidualnych zwiększył się do 87,9\%.

Jeszcze przed przystąpieniem Polski do Unii Europejskiej przyjęto lub znowelizowano wiele aktów prawnych, których celem była poprawa struktury obszarowej gospodarstw i przeciwdziałanie nadmiernej koncentracji nieruchomości rolnych. Po integracji z UE polskie rolnictwo zostało objęte szeregiem instrumentów Wspólnej Polityki Rolnej, co stworzyło możliwości szybszego rozwoju obszarów wiejskich. Największy wpływ na strukturę obszarową gospodarstw rolniczych miały renty strukturalne oraz płatności bezpośrednie. Oddziaływanie innych instrumentów, ze względu na ograniczoną liczbę beneficjentów, było mniejsze. Obrót ziemią kształtowały także kolejne regulacje prawne. Mimo różnokierunkowych działań po akcesji Polski do UE nie zdołano zlikwidować, a nawet znacznie ograniczyć problemu rozdrobnienia rolnictwa. W 2018 r. 53,4\% gospodarstw rolnych posiadało mniej niż 5 ha UR. Z kolei odsetek gospodarstw dużych o powierzchni 50 ha i więcej stanowił tylko 2,4\%. Średnia powierzchnia gospodarstwa rolnego wynosiła 10,65 ha. Dominującą formą własności w rolnictwie jest sektor indywidualny, który obejmuje ponad $92 \%$ UR.

Względy ekonomiczne wskazują, że polskie rolnictwo wymaga dalszych zmian strukturalnych. Gospodarstwa o stosunkowo małej powierzchni nie mają, bowiem możliwości osiągnięcia dochodu na odpowiednim poziomie. Rozdrobnienie agrarne gospodarstw ogranicza postęp i zwiększa jednostkowe koszty produkcji. To ogranicza konkurencyjność polskich gospodarstw na rynku Unii Europejskiej. W kształtowaniu struktury agrarnej należy jednak brać pod uwagę nie tylko uwarunkowania ekonomiczne, ale także społeczne i środowiskowe. 


\section{Bibliografia}

\section{Źródła drukowane}

Dziennik Ustaw Rzeczypospolitej Polskiej 1991, 2003, 2011, 2016

Historia Polski w liczbach, z. 2: Rolnictwo. Leśnictwo, Warszawa I991.

Leszczyńska C., Polska IgI8-2018. Historia Polski w liczbach, t. 5, Warszawa 2018.

Rocznik statystyczny 1957 , Warszawa 1957.

Rocznik statystyczny 196I, Warszawa 1961.

Rocznik statystyczny 1971, Warszawa 1971.

Rocznik statystyczny 1992, Warszawa 1992.

Rocznik statystyczny 2005, Warszawa 2005.

Rocznik statystyczny 2013, Warszawa 2013.

Rocznik statystyczny 2015, Warszawa 2015.

Rocznik statystyczny 2017, Warszawa 2017.

Rocznik statystyczny 2019, Warszawa 2019.

Rolniczy Rocznik Statystyczny 1945-1965, Warszawa 1966.

\section{Literatura}

Augustyńska-Grzymek I., Zmiany spoteczno-gospodarcze na wsi a ukierunkowanie produkcyjne w gospodarstwach rolnych, „Roczniki Naukowe Stowarzyszenia Ekonomistów Rolnictwa i Agrobiznesu" 20II, t. XIII, z. I.

Bański J., Historia rozwoju gospodarki rolnej na ziemiach polskich, [w:] Cztowiek i rolnictwo, red. Z. Górka, A. Zborowski, Kraków 2009.

Bożek J., Bogocz D., Przestrzenne zróżnicowanie struktury agrarnej województw w ujęciu dynamicznym, „Zeszyty Naukowe Małopolskiej Wyższej Szkoły Ekonomicznej w Tarnowie” 20I2, t. 20, $\mathrm{nr}$ I.

Czerniewski K., Zagadnienia struktury agrarnej, Warszawa 1937.

Czyżewski A., Henisz-Matuszczak A., Rolnictwo w Unii Europejskiej i Polsce. Studium porównawcze struktur wytwórczych i regulatorów rynków rolnych, Poznań 2006.

Dziurzyński P., Osadnictwo rolne na Ziemiach Odzyskanych, Warszawa 1983.

Dzun W., Gospodarstwa rolne o obszarze do I ha w procesie przemian systemowych i integracji $z$ UE, „Wieś i Rolnictwo” 2017, $\mathrm{nr}$ I (174).

Grzelak E., Polskie rolnictwo w XX wieku (Produkcja i ludność), Warszawa 2010.

Jankowiak S, Wielkopolski kutak wrogiem państwa socjalistycznego, „Biuletyn Instytutu Pamięci Narodowej" 2002, nr I.

Jarosz D., Polityka wtadz komunistycznych w Polsce w latach 1948 -1956 a chtopi, Warszawa 1998.

Kaliński J., Przemiany struktury obszarowej gospodarstw chtopskich w Polsce po IgI8 roku, „Kwartalnik Kolegium Ekonomiczno-Społecznego. Studia i Prace. Szkoła Główna Handlowa” 20I8, nr 3 .

Kaliński J., Transformacja gospodarki polskiej w latach 1989-2004, Warszawa 2009. 
Kaliński J., Landau Z., Gospodarka Polski w XX wieku, Warszawa 2003.

Kapusta F., Drogi i bezdroża gospodarstw rodzinnych w Polsce, „Problemy Drobnych Gospodarstw Rolnych" 2013, nr 2.

Karwat-Woźniak B., Chmieliński P., Przemiany w strukturze agrarnejpolskiego rolnictwa i wptyw wybranych instrumentów WPR na te procesy, „Prace Naukowe Uniwersytetu Ekonomicznego we Wrocławiu" 2016, nr 450.

Kersten K., Polski Komitet Wyzwolenia Narodowego 22 VII - 3 I XII 1944, Lublin 1965.

Kieniewicz S., Historia Polski 1795-1918, Warszawa 1996.

Klepacki B., Żak A., Przemiany agrarne na terenach polskich przed i po integracji z Unia Europejska, ,Journal of Agribusiness and Rural Development" 2014, nr 4 (30).

Kłopot S.W., Struktura agrarna indywidualnego rolnictwa w latach 1945-2010, „Annales Universitatis Mariae Curie-Skłodowska” 20II, vOL. XxxvI, z. 2, Sectio I.

Konopka K., Konieczność reform agrarnych w Drugiej Rzeczypospolitej Polskiej (1918-1939), „Ekonomia i Zarządzanie” 2009, nr I (I).

Kostrowicka I., Landau Z., Tomaszewski J., Historia gospodarcza Polski XIX i XX wieku, Warszawa 1984.

Kuś J., Matyka M., Zmiany organizacyjne w polskim rolnictwie w ostatnim Io-leciu na tle rolnictwa $U E$, „Zagadnienia Ekonomiki Rolnej” 2014, nr 4 (34I).

Marks-Bielska R., Kisiel R., Danilczuk J., Dzierżawa jako podstawowa forma zagospodarowania popegeerowskiego mienia, Olsztyn 2006.

Michałek M., Przemiany polskiej wsi w latach 1918-1989, „Klio” 2013, nr 26 (3).

Mickiewicz B., Wptyw regulacji prawnych na zmianę struktury agrarnej w Polsce po IggI roku, „Roczniki Naukowe Stowarzyszenia Ekonomistów Rolnictwa i Agrobiznesu” 2013, t. XV, z. I.

Mieszczankowski M., Rolnictwo II Rzeczypospolitej, Warszawa 1983.

Mieszczankowski M., Struktura agrarna Polski międzywojennej, Warszawa 1960.

Nadolski M., Komuniści wobec chtopów w Polsce 194I-1956. Mity i rzeczywistość, Warszawa 1993.

Noniewicz Cz., Reforma rolna na Wileńszczyźnie wokresie międzywojennym, „Optimum. Studia ekonomiczne" 2014, nr 6 (72).

Oleszko A., Prawo rolne, [w:] Encyklopedia Agrobiznesu, Warszawa 1998.

Pietrzak M.B., Walczak D., The analysis of the agrarian structure in Poland with the special consideration of the years 1921 and 2002, "Bulgarian Journal of Agricultural Science” 2014, No. 20.

Podedworna H., Polscy farmerzy i ich świat spoteczny, Warszawa 2001.

Rogala W., Dziatalność Państwowych Nieruchomości Ziemskich (1946-1949), „Rocznik Muzeum Rolnictwa w Szreniawie" 1972, t. 5 .

Runowski H., Ziętara W., Stan dotychczasowy i rekomendacje na przysztość w procesie przeksztatceń wtasnościowych, [w:] Przeksztatcenia wtasnościowe w rolnictwie - Io lat doświadczeń, Warszawa 2002.

Sikorska A.M., Przemiany w strukturze agrarnej indywidualnych gospodarstw rolnych, Warszawa 2013.

Skodlarski J., Zarys historii gospodarczej Polski, Warszawa 2007.

Stabek H., Dzieje polskiej reformy rolnej 1944-1948, Warszawa 1972. 
Szemberg A., Struktura agrarna i polityka strukturalna, [w:] Encyklopedia Agrobiznesu, Warszawa 1998.

Szuba E., Poczta W., Efekty integracji Polski z Unia Europejska w sektorze rolnym. Referat wygtoszony na IX Kongresie Ekonomistów Polskich, $28-29$ listopada 2013 r., Warszawa 2013.

Szymańska E., May J., Structural changes in the agriculture in Poland in the years 19go-2016, „Agrarna Ekonomika” 2018, t. II, nr 3/4.

Wigier M., Polityka rolna i zmiany strukturalne w rolnictwie polskim po akcesji do UE, „Prace Naukowe Uniwersytetu Ekonomicznego we Wrocławiu” 2014, nr 360.

Wilkin J., Wspótczesna kwestia agrarna, Warszawa 1986.

Winiewska R., Obciażenia podatkowe gospodarstw chtopskich w Polsce w latach 1945-1955, Warszawa 1961.

Woś A., Prognoza przeksztatceń strukturalnych polskiego rolnictwa do 2020, Warszawa 1996.

Zegar J.S., Kwestia koncentracji ziemi w polskim rolnictwie indywidualnym, „Roczniki Nauk Rolniczych" 2009, t.96, z. 4 .

Zegar J.S., Polskie rolnictwo w okresie dwóch przetomów - transformacji ustrojowej i integracji europejskiej, „Nierówności Społeczne a Wzrost Gospodarczy” 2015, nr 4I.

Zegar J.S., Wspótczesne wyzwania rolnictwa, Warszawa 2012.

Ziętara W., Spoteczny czy ekonomiczny charakter reform rolnych $w$ Polsce w okresie między-i powojennym, „Roczniki Naukowe Ekonomii Rolnictwa i Rozwoju Obszarów Wiejskich” 2015, t. IO2, z. I.

Żmija D., Wptyw wybranych instrumentów wspólnej polityki rolnej na zmiany w zasobach ziemi matych gospodarstw rolnych z województwa matopolskiego, „Roczniki Naukowe Stowarzyszenia Ekonomistów Rolnictwa i Agrobiznesu" 2017, t. XIX, z.3.

Streszczenie: W opracowaniu dokonano analizy zmian w strukturze agrarnej polskiej wsi w latach 19I8-20I8. Znajomość kierunków i uwarunkowań tych zmian jest niezbędna do prawidłowego sformułowania celów polityki rolnej. Ze względu na uwarunkowania historyczne w analizie wyodrębniono cztery okresy: okres międzywojenny, czas wojny i gospodarki socjalistycznej, okres od transformacji ustrojowej do integracji z UE oraz okres po przystąpieniu Polski do Unii Europejskiej. Z analiz wynika, że w ostatnim stuleciu w rolnictwie polskim zaszly istotne przemiany w strukturze agrarnej polskiego rolnictwa. W poszczególnych okresach historycznych były determinowane różnymi czynnikami o charakterze politycznym, gospodarczym i społecznym. W związku z tym ich charakter i kierunek zmieniał się w czasie. W całym analizowanym okresie dominowała własność prywatna gospodarstw rolnych. Mimo różnych działań nie zdołano zlikwidować rozdrobnienia polskiego rolnictwa. W $2018 \mathrm{r}$. ponad połowa gospodarstw rolnych posiadała mniej niż 5 ha UR. Z kolei odsetek gospodarstw dużych o powierzchni 50 ha i więcej stanowił tylko 2,4\%. Taki stan struktury agrarnej z perspektywy przyrodniczo-krajobrazowej korzystnie wpływa na środowisko ale pod względem ekonomiczno-produkcyjnym wymaga poprawy.

Słowa klucze: struktura agrarna, formy własności, gospodarstwa, regulacje prawne, instrumenty WPR 
Summary: The study analyzes changes in the agrarian structure in the Polish countryside in the years 1918-2018. Knowledge of the directions and conditions of these changes is necessary for the correct formulation of agricultural policy objectives. Due to historical conditions, the analysis distinguishes four periods: the interwar period, the time of war and the socialist economy, the period from the political transformation to integration with the EU and the period after Poland's accession to the European Union. The analyzes show that in the last century in Polish agriculture significant transformations occurred in the agrarian structure of Polish agriculture. In particular historical periods they were determined by various political, economic and social factors. Therefore, their character and direction changed over time. Private ownership of farms dominated in the whole analyzed period. Despite various actions, the fragmentation of Polish agriculture could not be eliminated. In 2017, more than half of agricultural holdings had less than 5 ha of UAA. In turn, the percentage of large farms with an area of 50 ha and more accounted for only $2.4 \%$. This state of agrarian structure has a positive impact on the environment but in terms of economic and production needs improvement.

Keywords: area structure, ownership forms, holdings, legal regulations, CAP instruments 